\title{
Study of Certain Biomarkers in Iraqi Female Patients with Breast Cancer
}

\author{
Abeer M. Hussain ${ }^{1 *} \quad$ Ali Hussein Mohammed AL-Khafaji ${ }^{2} \quad$ Alia Hussain Ali ${ }^{3}$ \\ Haider Latif Mohammed ${ }^{4}$ \\ ${ }^{1}$ Department of Biology, College of Science for Women, University of Baghdad, Baghdad, Iraq. \\ ${ }^{2}$ Collage of Densitry, Uruk University. \\ ${ }^{3}$ Department of Biology, College of Science for Women, University of Baghdad, Baghdad, Iraq. \\ ${ }^{4}$ Ministry of Health, AL-Wasity Teaching Hospital. \\ *Corresponding author: abeer.m@csw.uobaghdad.edu.iq ${ }^{*}$, Alkhafaji3@yahoo.com, aliaha_bio@csw.uobaghdad.edu.iq , \\ haiderlteef5@gmail.com. \\ *ORCID ID: https://orcid.org/0000-0002-8452-6127* , https://orcid.org/0000-0001-5573-5942 .
}

Received 1/11/2019, Accepted 5/1/2020, Published Online First 30/4/2021, Published 1/12/2021

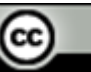

\begin{abstract}
:
The prospective study has been designed to determine some biomarkers in Iraqi female patients with breast cancer. The current study contained 30 patients whose tissue samples have been collected from hospitals in Medical City in Baghdad after consent patients themselves and used immunohistochemical technique to determine these markers. The results showed a significant correlation between ER and PR tissue markers $(\mathrm{Sig}=0.000)$ and a significant correlation between cyclin E phenotype and cyclin E intensity $($ Sig $=$ $0.001)$.
\end{abstract}

Keywords: Breast cancer, Cyclin E, ER, Her-2/neu, PR.

\section{Introduction:}

Breast cancer is the most common cancer in women (1).It's the most diagnosed cancer that causes death in women and it is noticed to be a higher incidence in developed countries with higher death rates in developing countries (2).Most breast cancer begins either in glands for milk secretion called (lobule) or in ducts that are attached with lobule and nipple (3). Breast tumor may be benign or malignant (cancerous) (4). Hormone receptors are a group of substances in tumor tissue that is used for diagnosing and predicting of breast cancer. These receptors include Estrogen Receptor (ER), Progesterone Receptor (PR), Human Epidermal Growth Factor Receptor (Her - 2) (5) and Cyclin E (6).Estrogen and Progesterone receptors are intracellular receptors that estimated estrogen activity, estrogen pass through cell membrane and bind with ER in nucleus and transforming the receptor and bind to specific response elements known as estrogen response elements (EREs) that localized in promoter of target genes (7). Estrogen receptor and Progesterone receptor are prognosis and predictive marker that have a strong relation with therapeutic decision (6). Estrogen receptor (ER) is found in two main types: $\operatorname{ER} \alpha$ and $\operatorname{ER} \beta$; also progesterone receptor (PR) is found in two types: PRA and PRB (5). The increased exposure is to estrogens, early menarche and late menopause (8) and high serum levels of estradiol (E2), testosterone and other estrogens and androgens, also decreased levels of sex hormone-binding globulin (SHBG) have been found to be contributed in the incidence of breast cancer (9). There are three forms of physiological estrogen in females: estrone (E1), estradiol (E2, or 17 $\beta$-estradiol), and estriol (E3).The high level of estrone (E1) in pre-and postmenopausal women enhanced risk of breast cancer. Estradiol (E2) is a widely accepted theory with widely experimental findings, that influence breast cancer development by acting through ER $\alpha$ that induced cell proliferation and initiates mutations that causes error during DNA replication and then the growth of cells bearing mutations with accumulate these mutations ultimately result cancer (8). Estrogen and Progesterone receptors are important to determine in patients to start adjuvant therapy (Tamoxifen) that considered a most endocrine treatment which block E2 binding (10) and Neoadjuvant therapy describe before surgery to decrease the size of un-resected tumor and may be to the reduction of mastectomy (11). 
Human epidermal growth factor receptor (Her - 2) was first discovered in 1984 by Weinberg and associated (12).The genes that encoded to this receptor are situated on chromosome 17q (13)and called as a neu in rat, the gene expression result production $185 \mathrm{kDa}$ transmembrane glycoprotein are known as Her -2 protein and have extracellular domain (ECD) (14). Human epidermal growth factor receptor -2 as tyrosine kinase activity have a control on cellular division and as repair function in breast cell but over expression of Her -2 termed as Her -2 positive $(\mathrm{Her}-2+$ ) can cause an un-controlled growth and division for breast cell (15).The overexpressed Her-2 leads to neoplastic transformation and malignancy performance(16). Human epidermal growth factor receptor -2 in breast cancer tissue is considered as a prognostic factor that is related to disease - free or survival in absence of adjuvant therapy and as predictive factor associated the response to taken therapy (17).There is a large number of therapies targeted Her -2 receptor in breast cancer tumor including trastuzumab (Herceptin) for breast cancer patients (18).

Cyclin E / CCNE1 gene is localized on chromosome 19q (19).Cyclin E a nuclear protein first identified through its ability of division defects in cyclin - deficient yeast cells (20).In early yeast genetics that were discovered first is cyclin dependent kinase (CDK) then known as cell division cycle $2(c d c 2)$ but now refers to as CDK1 (21).This enzyme contains two subunits: a catalytic CDK and a regulatory cyclin that activated CDK (20). In breast cancer cells, cyclin $\mathrm{E}$ gene is amplified and expressed the cyclin $\mathrm{E}$ protein and over expression for Cyclin E full length $50-\mathrm{kDa}$ (EL) (22). The full - length cyclin E (EL) and by proteolytic cleavage transformed to low molecular weight (LMW - E) by neutrophile elastase and these LMW are (EL2 (33 kDa) and EL4 (45 kDa) is uniquely expressed in tumor cell (23).In eukaryote cell cycle, the Cyclin and CDK controlled cell cycle through four - phases of cell cycle (G1, S, $\mathrm{G} 2$ and $\mathrm{M})$, when the cell begins preparing in $\mathrm{G} 1$ phase that controlled by Cyclin D/CDK4/6 and Cyclin E/CDK2 at the so-called G1/S transition and then DNA replicated in $S$ phase after that beginsG2 phase and in the end begins cyclin $\mathrm{B} / \mathrm{CDK} 1$ controlled entry cell into $\mathrm{M}$ phase (mitosis) that begins cell division (24).

\section{Materials and Methods:}

The current study contained 30 tissue samples of breast cancer patients collected after surgery (mastectomy) that collected from patients as (Formalin Fixed Paraffin Embedded Tissue
"FFPE") who attended the Oncology Teaching Hospital in Medical City in Baghdad. The Estrogen receptor, Progesterone receptor, Human epidermal growth factor receptor-2 kits used belongs to Zytomed company, Germany and cyclin E kit used for Bio SB, U.S.A. The tissue section slides of ER, PR, Her - 2/neu and Cyclin E receptors were imaged by using light Microscope (leica) and camera (leica) by $10 \mathrm{X}$ and $40 \mathrm{X}$ objective lenses and magnification power at $100 \mathrm{X}$ and $400 \mathrm{X}$.

\section{Immunohistochemistry}

The purpose of immunohistochemistry staining is to make tissue and cell antigens visible in fixed paraffin - embedding tissue sections. This method is based on streptavidin - biotin system which means that a biotinylated secondary antibody is bind to several molecules of a conjugate composed of streptavidin and horse radish peroxidase.

\section{Estrogen Receptor immunohistochemistry}

-Prepared $500 \mathrm{ml}$ of $10 \%$ dilution of antigen retrieval PH 6.

-Prepared $600 \mathrm{ml}$ of $10 \%$ diluted wash buffer.

- Chromogenic substrate was prepared by adding one drop of concentrated DAP of $1 \mathrm{ml}$ from buffer.

- Hematoxylin stain was prepared by adding $1 \mathrm{ml}$ from stain to $1 \mathrm{ml}$ distilled water.- -Ready to use of ER primary antibody was used.

- Deparaffinization: the sectioning slide from block, inserted in oven $60{ }^{\circ} \mathrm{C}$ for quarter - hour to remove wax rounded to tissue, then put slides in xylole for 5 minutes to remove wax dissolvent and repeated this process 2 times to ensure remove all the wax around the tissue.

- Slides in antigen retrieval were put in oven at $98^{\circ} \mathrm{C}$ for 1 hour.

- The slide was washed with wash buffer for 5 minutes.

-Humid chamber was prepared by putting an absorbent paper in slide container and some drops of water were put.

- Tissue was trapped by (pap pen mini), $40-60 \mu 1$ peroxide block were added on the slide by micropipette and the slides were put inside slide container for quarter - hour.

- Slides were washed with wash buffer, left for 5 minutes and any remaining wash buffer was removed by an absorbent paper.

$-40 \mu \mathrm{l}$ ER primary antibody were added on slides then incubated for $30-45$ minutes in humid chamber. The amount of added antibody depends on the tissue size on the slide.

-Slides were washed by the wash buffer for 5 minutes and any remaining wash buffer was removed by an absorbent paper. 
$-40-45 \mu 1$ of HRP was added for quarter - hour in humid chamber.

- Slides were washed with wash buffer.

- DAB was added for 10 minutes and slides were put inside humid chamber.

- Slides were washed with wash buffer.

- Counter stain was added for 30 seconds.

- Slides were washed by tapping water until removing excessive hematoxylin stain.

- The slides were dried in oven to drain off water.

-Slides was mounted by adding DPX and covered by cover histo slide.

The determination of Progesterone receptor, Human epidermal growth factor receptor-2 and Cyclin E are similar to the steps of Estrogen receptor procedure but the difference is in two steps: step 5 and step 12 that used the specific primary antibody for each receptor.

Estrogen receptor and Progesterone receptor section reading

The ER, PR section was read according to the Allred score (proportional percentage+ intensity of staining) of tumor cells and these readings were according to (25) as in the Table 1.

Table 1. Allred score of ER and PR sections.

\begin{tabular}{lll}
\hline $\mathbf{N}$ & Allred score & Final result \\
\hline 1 & $0 / 8$ & Negative \\
2 & $1 / 8-2 / 8$ & Negative \\
3 & $3 / 8-4 / 8$ & + ve Weak \\
4 & $5 / 8-6 / 8$ & + ve Moderate \\
5 & $7 / 8-8 / 8$ & + ve Strong \\
\hline
\end{tabular}

Her-2/neu section was reading according (25) as Table 2.

Table 2. The score of Her-2/neu depend on intensity of staining cells

\begin{tabular}{|c|c|c|}
\hline $\mathbf{N}$ & Staining Pattern & Score of Her-2 \\
\hline 1 & $\begin{array}{l}\text { No staining the tumor cells < } \\
10 \%\end{array}$ & $0(-\mathrm{ve})$ \\
\hline 2 & $\begin{array}{l}\text { Faint / incomplete membrane } \\
\text { staining in tumor cells }>10 \%\end{array}$ & $-1(-v e)$ \\
\hline 3 & $\begin{array}{l}\text { Weak to moderate complete } \\
\text { membrane staining in tumor } \\
\text { cells }>10 \%\end{array}$ & $+2(+\mathrm{ve})$ \\
\hline 4 & $\begin{array}{l}\text { Strong complete membrane } \\
\text { staining in tumor cells }>10 \%\end{array}$ & $+3(+\mathrm{ve})$ \\
\hline
\end{tabular}

The immunohistochemical reading for cyclin $\mathrm{E}$ protein are divided into two types according to (23, 26) as in two Tables 3 and 4.
Table 3. First reading of cyclin $\mathbf{E}$ according to Phenotype

\begin{tabular}{ll}
\hline N & First reading according to Phenotype \\
\hline 1 & Phenotype I = no nuclear and No cytoplasm \\
2 & $\begin{array}{l}\text { Phenotype II }=+ \text { nuclear and No or weak } \\
\text { cytoplasm }\end{array}$ \\
3 & $\begin{array}{l}\text { Phenotype III }=+ \text { nuclear and + cytoplasm } \\
4\end{array}$ \\
$\begin{array}{l}\text { Phenotype IV }=\text { no or weak nuclear and }+ \\
\text { cytoplasm }\end{array}$ \\
\hline
\end{tabular}

Table 4. Second reading of cyclin $E$ according to Intensity of tumor cells

\begin{tabular}{ll}
\hline $\mathbf{N}$ & $\begin{array}{l}\text { Second reading according to Intensity of } \\
\text { tumor cells }\end{array}$ \\
\hline 1 & No Stain \\
2 & Weak \\
3 & Intermediate \\
4 & Strong \\
\hline
\end{tabular}

\section{Statistical Analysis}

The collected data was introduced into Microsoft excel sheet 2016, and loaded into SPSS v23. Correlation test was used to find out significance of correlation between related variables. Probability value ( $\mathrm{P}$ value) less than 0.05 was considered as discrimination point for alpha error (significance) in all used statistical tests.

\section{Results}

This study was designed to determine certain tissue markers in Iraqi female patients who were diagnosed to have breast cancer. The tissue markers were collected from patients who attended hospital in Baghdad and the patients' information was collected from the patients themselves. The patients' ages and body mass index means are showed in Table 5. The body mass index for patients is determined according the equation $\left(\mathrm{BMI}=\frac{\text { Whight }}{\text { (Heat)2 }}\right)(27)$. The patients' children number, smoking, hypertension, diabetes, breast feeding, oral contraceptive pills, family history, stage and grade are illustrated as in Table 6.

Table 5. Illustrated the patient ages and body mass index (BMI) means for patients studied.

\begin{tabular}{lll}
\hline No. & Studied Variables & Mean \\
\hline 1 & Age & 52.133 \\
2 & Body mass index & 30.5 \\
\hline
\end{tabular}


Table 6. Illustrated the patients children number, smoking, chronic disease, breast feeding, family History, Stage and Grade.

\begin{tabular}{|c|c|c|}
\hline No & Studied Variables & \\
\hline \multirow{3}{*}{1} & Children Number & \\
\hline & Yes (have children) & 24 \\
\hline & No( have no children) & 6 \\
\hline \multirow[t]{3}{*}{2} & Smoking & \\
\hline & Yes(smoker) & 1 \\
\hline & No (non smoker) & 29 \\
\hline \multirow[t]{3}{*}{3} & Hypertension & \\
\hline & Yes( have hypertension) & 8 \\
\hline & No( have not hypertension) & 22 \\
\hline \multirow[t]{3}{*}{4} & Diabetes & \\
\hline & Yes( have diabetes) & 5 \\
\hline & No(not have diabetes) & 25 \\
\hline \multirow[t]{3}{*}{5} & Breast Feeding & \\
\hline & Yes( breast feed) & 24 \\
\hline & No( no breast feed $)$ & 6 \\
\hline \multirow[t]{3}{*}{6} & Oral Contraceptive pills & \\
\hline & Yes(taking contraceptive pills) & 2 \\
\hline & No( not taking contraceptive pills) & 28 \\
\hline \multirow[t]{3}{*}{7} & Family History & \\
\hline & Yes(have first-degree history) & 3 \\
\hline & No( have no first-degree history) & 27 \\
\hline \multirow[t]{4}{*}{8} & Stage & \\
\hline & Stage I & 1 \\
\hline & Stage II & 12 \\
\hline & Stage III & 17 \\
\hline \multirow[t]{4}{*}{9} & Grade & \\
\hline & Grade I & 1 \\
\hline & Grade II & 20 \\
\hline & Grade III & 9 \\
\hline
\end{tabular}

The results for ER and PR receptors were ER positive cases $70 \%(21 / 30)$ and PR positive cases were $73 \%$ (22/30). ER was $23 \%$ (7 / 30) had a strong stain and $30 \%(9 / 30)$ positive PR cases had a strong stain as in Table 7 .

Table 7. Showed the results for ER and PR.

\begin{tabular}{|c|c|c|}
\hline $\begin{array}{l}\text { ER and PR } \\
\text { Phenotype }\end{array}$ & Number & Percentage $\%$ \\
\hline $\mathrm{ER}+/ \mathrm{PR}+$ & 21 & 70 \\
\hline $\mathrm{ER}+/ \mathrm{PR}-$ & 0 & 0 \\
\hline $\mathrm{ER}$ - / PR + & 1 & 3.3 \\
\hline ER - / PR - & 8 & 26.6 \\
\hline Total & 30 & 100 \\
\hline
\end{tabular}

The Her-2/neu results showed (14 / 30) of cases were malignant $46.6 \%$ are positive for Her -2 /neu protein expression, while (6/30) $20 \%$ are score 1 Her -2 / neu which are considered Her -2 / neu negative. Her - 2 immunohisto scoring $23.3 \%$ (7 / 30) score 3 patients having strong positive Her-2 / neu that means Her -2 genes are over - producing Her - 2 protein and those cells were growing rapidly and creating a cancer, while $33.3 \%$ (10/ 30) had score $0 \mathrm{Her}-2$ asinTable 8.
Table 8. Her-2/neu percentage

\begin{tabular}{lll}
\hline $\begin{array}{l}\text { Her }-2 \text { / neu } \\
\text { status }\end{array}$ & Number & Percentage \% \\
\hline Score 0 Negative & 10 & 33.3 \\
Score 1 Negative & 6 & 20 \\
Score 2 Positive & 7 & 23.3 \\
Score 3 Positive & 7 & 23.3 \\
Total & 30 & 100 \\
\hline
\end{tabular}

The results of cyclin E phenotype and intensity are showed in Table 9.

Table 9. Cyclin E percentage

\begin{tabular}{lll}
\hline $\begin{array}{l}\text { Cyclin E / } \\
\text { phenotype }\end{array}$ & Number & Percentage \% \\
\hline $\begin{array}{r}\text { Phenotype I } \\
\text { Phenotype II }\end{array}$ & 3 & 11 \\
Phenotype III & 14 & 36.6 \\
Phenotype IV & 2 & 46.6 \\
Total & 30 & 6.6 \\
Cyclin E & Number & 100 \\
intensity & 3 & Percentage \% \\
No stain & 8 & 10 \\
Weak & 9 & 30.6 \\
Intermediate & 9 & 33.3 \\
Strong & 10 & 100 \\
Total & 30 & \\
\hline
\end{tabular}

\section{Tissue sections}

In invasive breast carcinoma the negative status of estrogen receptor (ER) and progesterone receptor (PR) mean that no ER and PR expression $(0 \%)$ staining cells and the nuclear staining $<1 \%$ of total cancer cells as illustrated in Fig.1.ER was 10\% expression from tumor cells with weak staining as in Fig. 2 and high expression 90\% with moderate staining as in Fig.3. The expression of PR was $10 \%$ with weak staining as in Fig, 4 while was $90 \%$ with strong staining as in Fig. 5.

Her-2/neu is a cell membrane receptor and its staining depends on the intensity of cancer cells staining. Figure 6 and 7 shows the higher expression of Her-2/neu that score $(+2$ and +3$)$ which shows reaction between the of her- $2 /$ neu receptor with immunostaining.

The Fig. 8 shows the phenotype II of cyclin E expression that occur nuclear staining exceeded cytoplasmic staining. Figure 9 the phenotype III of cyclin $\mathrm{E}$ that was nuclear and cytoplasmic staining are equal. Figure 10shows the phenotype IV of cyclin $\mathrm{E}$ that was cytoplasmic staining exceeded nuclear staining. 


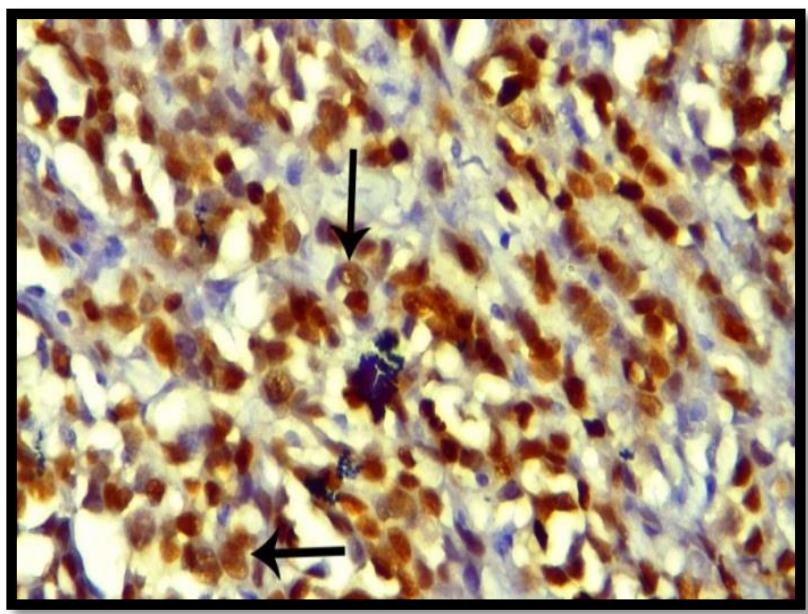

Figure 1. Negative. No breast cancer cells pigmented. $400 \mathrm{X}$.

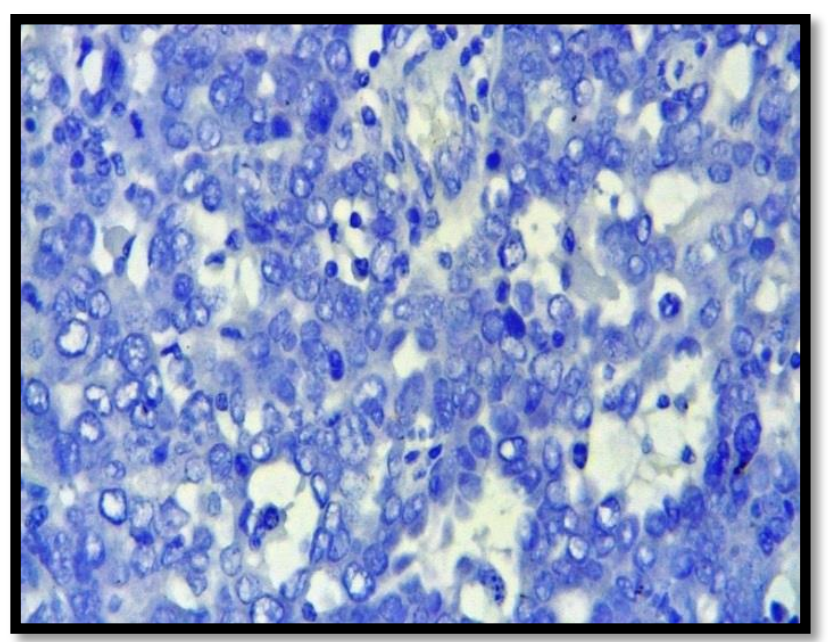

Figure 2. ER breast carcinoma $.10 \%$ (proportional) weak staining (intensity) $400 \mathrm{X}$.

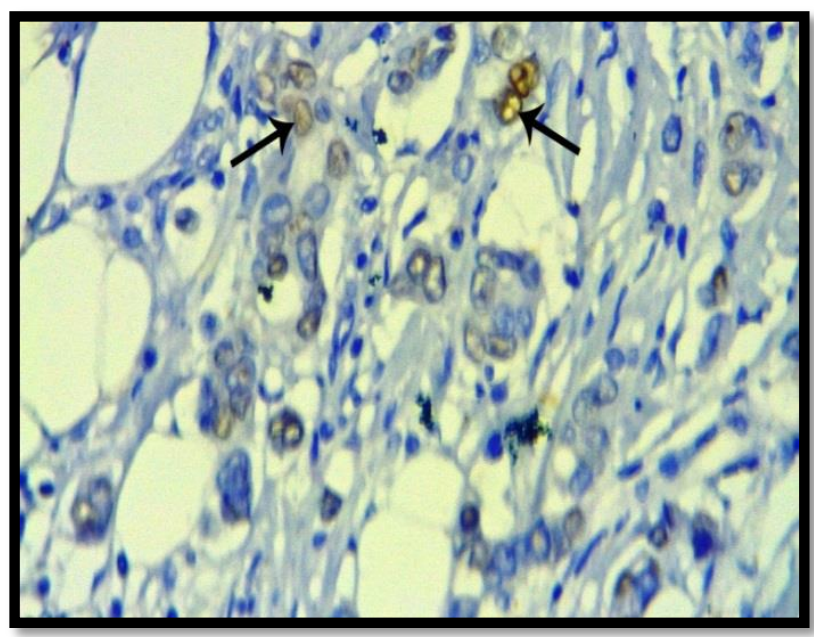

Figure 3. ER invasive lobular carcinoma. $90 \%$ (proportional) moderate staining (intensity) 400 $\mathbf{X}$.

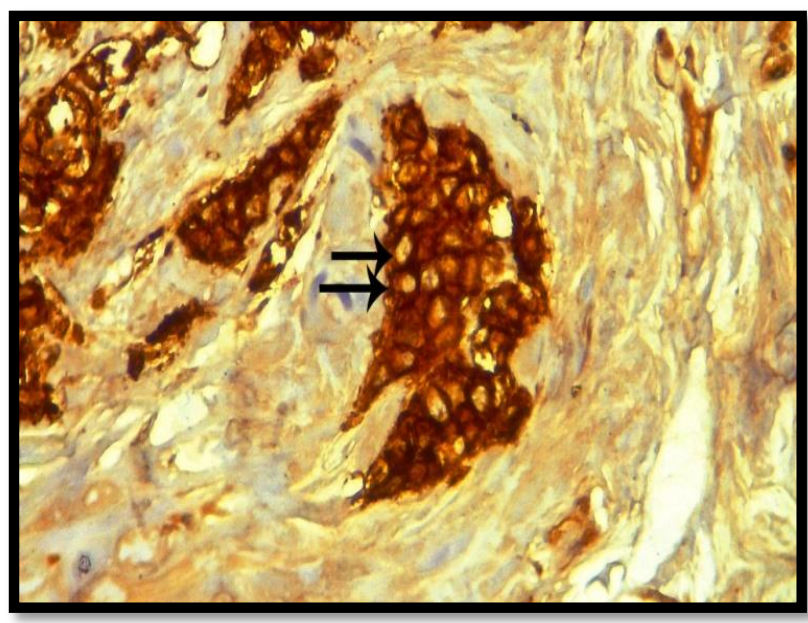

Figure 4. PR breast carcinoma. $10 \quad \%$ (proportional) Weak staining (intensity) $100 \mathrm{X}$.

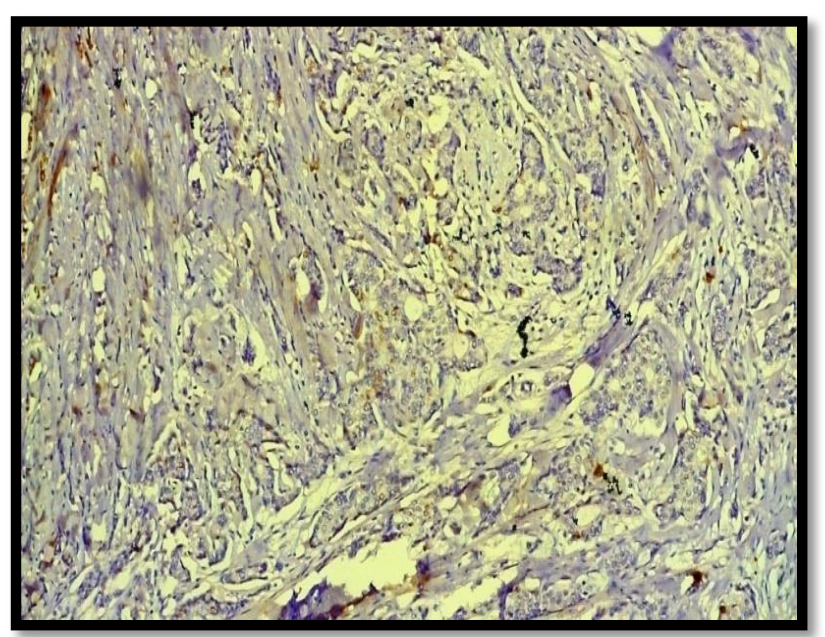

Figure 5. PR breast carcinoma. $90 \%$ (proportional) Strong staining (intensity) $400 \mathrm{X}$.

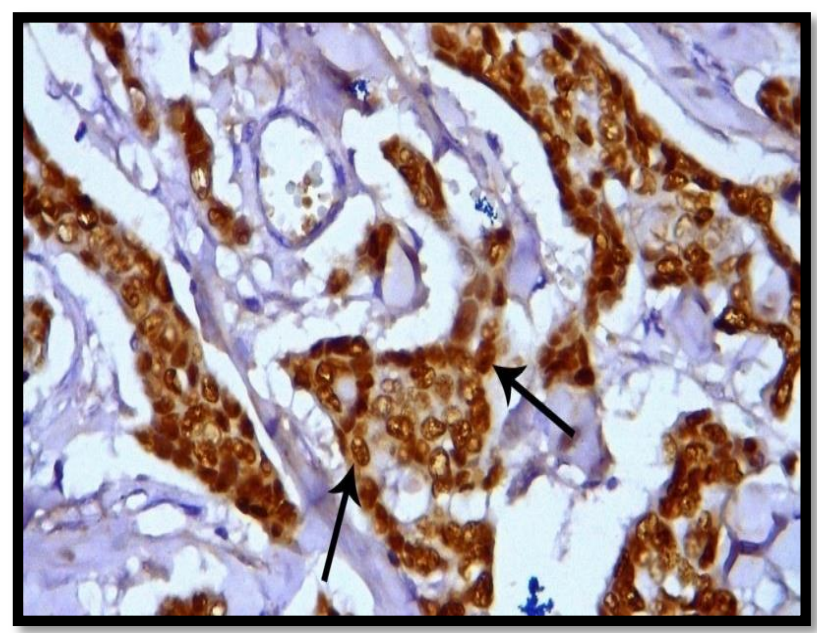

Figure 6. Her-2 /neu breast carcinoma. Score (2) + ve.400 X. 


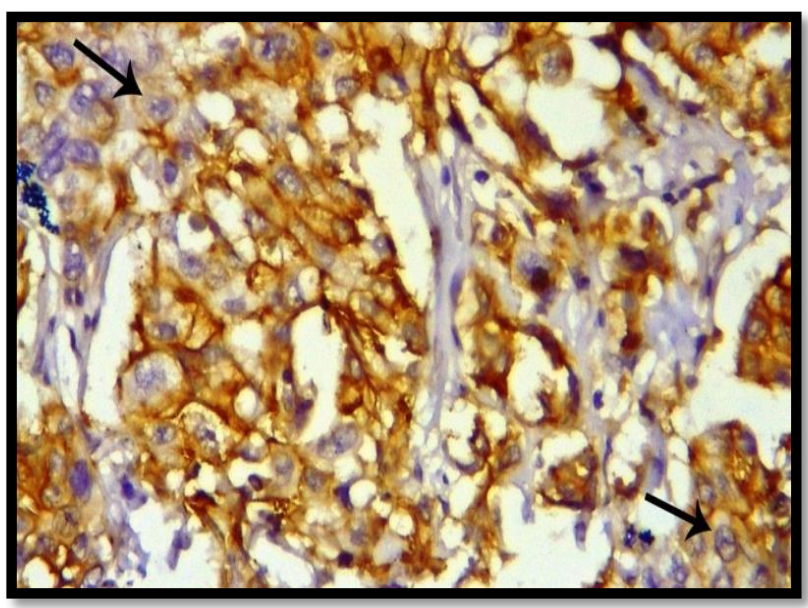

Figure 7. Her-2 /neu breast carcinoma. Score (3)+Ve.400 X.

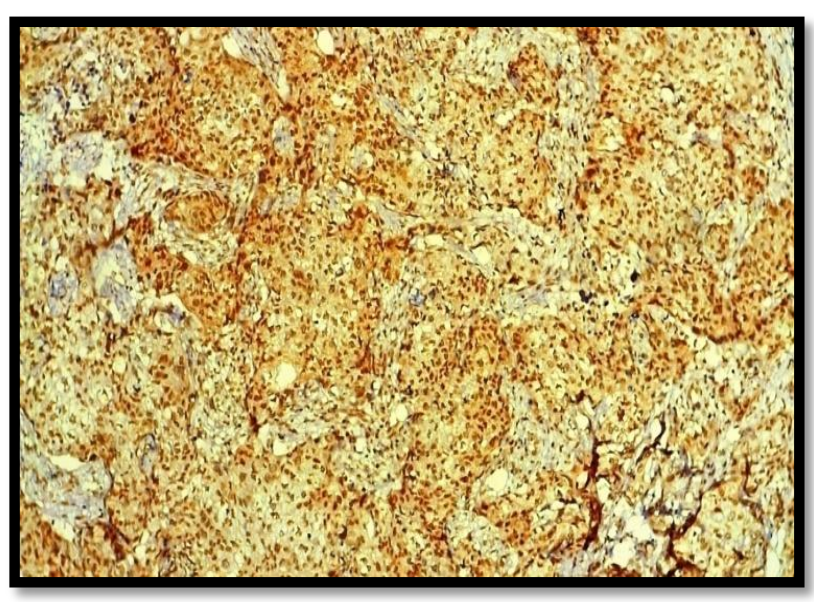

Figure 8. Cyclin E, phenotype II, +ve nuclear and weak cytoplasm. $100 \mathrm{X}$.

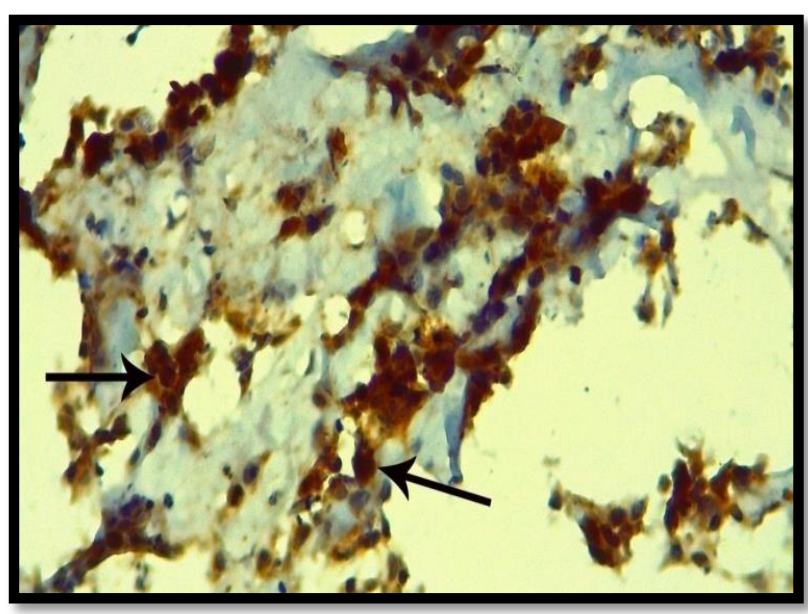

Figure 9. Cyclin E, phenotype III, +ve nuclear and +ve cytoplasm. $400 \mathrm{X}$.

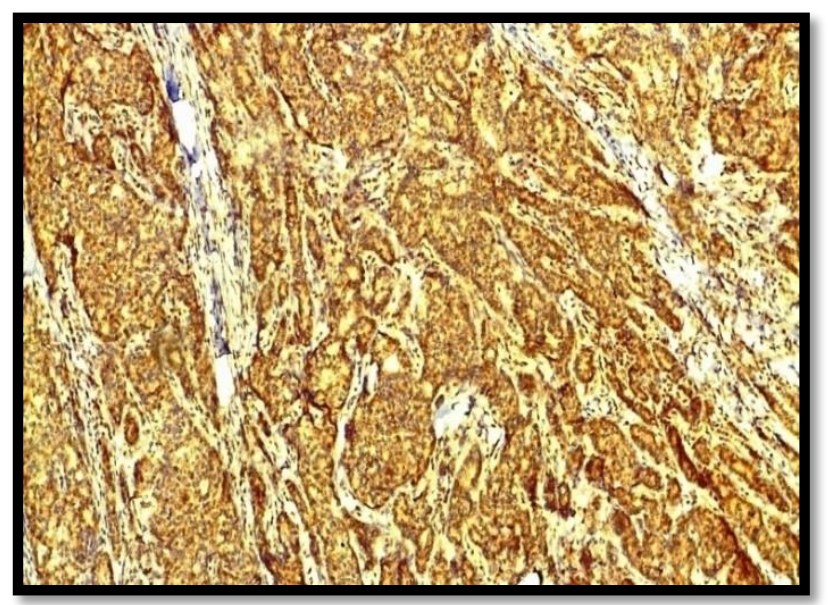

Figure 10. Cyclin E, phenotype IV,-Ve nuclear and +Ve cytoplasm. $100 \mathrm{X}$.

The correlation among tissue markers showed a significant correlation between ER score and PR score $(\mathrm{Sig}=0.000)$, positive correlation $(0.803)$ as in Table 10 and a significant correlation between cyclin E phenotype with cyclin E intensity $(\mathrm{Sig}=0.001)$, positive correlation $(0.521)$ as in Table 10.

Table 10. Explain correlation between tissue markers in studied breast tumor.

\begin{tabular}{|c|c|c|c|c|c|c|}
\hline \multicolumn{7}{|c|}{ Correlation between tissue markers in studied breast tumor } \\
\hline & & ER score & PR score & Her $-2 /$ neu & Cyclin E PH & Cyclin E INT \\
\hline \multirow[t]{2}{*}{ ER score } & Pearson Correlation & 1 & $0.803^{* *}$ & $-0.254-$ & $-0.038-$ & 0.055 \\
\hline & Sig. (2-tailed) & & 0.000 & 0.113 & 0.817 & 0.735 \\
\hline PR score & $\begin{array}{l}\text { Pearson Correlation } \\
\text { Sig. (2-tailed) }\end{array}$ & & 1 & $\begin{array}{l}-0.155- \\
0.341\end{array}$ & $\begin{array}{l}-0.043- \\
0.790\end{array}$ & $\begin{array}{l}-0.081- \\
0.619\end{array}$ \\
\hline \multirow[t]{2}{*}{ Her - 2 / Neu } & Pearson Correlation & & & 1 & 0.191 & 0.036 \\
\hline & Sig. (2-tailed) & & & & 0.237 & 0.827 \\
\hline \multirow[t]{2}{*}{ Cyclin E PH } & Pearson Correlation & & & & 1 & $0.521^{* *}$ \\
\hline & Sig. (2-tailed) & & & & & 0.001 \\
\hline Cyclin E INT & $\begin{array}{l}\text { Pearson Correlation } \\
\text { Sig. (2-tailed) }\end{array}$ & & & & & 1 \\
\hline **. Correlatiol & is significant at the 0 . & (2-tailed). & & & & \\
\hline
\end{tabular}




\section{Discussion:}

This study showed a significant correlation Sig. (0.000) and positive correlation (0.803) between ER and PR score. This correlation agrees with Mahir et al. study that showed a significant correlation between ER and PR and the significance was Sig. (0.000) (28). As well as statistically significant correlation Sig. $(<0.001)$ between ER and PR and this correlation is due to the theory of ER dependent PR synthesis (29).

Horwitz, K. B. and McGuire, W. L. showed that when MCF-7 cell line exposed to continues estrogen treatment that achieving ER levels prior progesterone receptor $(\mathrm{PgR})$ induction, firstly the induction is slow then stimulated PgR levels are maintained as long as estrogen is present and when estrogen treatment is removed, this processing is stopped and PgR levels fall to basal values (30).

The positive correlation is Sig (0.001) between phenotype and intensity cyclin E. The cyclin E is composed of low molecular weight (LMW-E) which specially expressed in tumor cell, LMW-E expression found by western blotting analysis correlated with cytoplasmic staining for cyclin E on IHC due to LMW - E lacks the nuclear localization and accumulates in cytoplasm, binds with CDK2 and begin kinase activity (23). Low Molecular Weight - E reported is more active than full length, higher affinity for binds with CDK2 and more tumorigenic and the result showed that patients with higher expressed for LMW - E have a higher risk for recurrence and death because breast cancer (26). Dubowy et al. explained that existing cyclin E in cytoplasm through proliferation in endometrium and bind with it's partner CDK2 within cytoplasm and move from cytoplasm to nucleus in differentiating cells and begin increased nuclear cyclin $\mathrm{E}$ concentrations with decrease levels in cytoplasm (31).

The cyclin $\mathrm{E}$ phenotype in cytoplasm or nucleus is suggested to have a positive correlation with intensity. Cyclin E as observed it higher expressed in breast cancer with increased intensity and by its function, it is found in cytoplasm firstly and move toward nucleus, so the intensity binds with two localization in cells.

\section{Conclusion:}

Breast cancer is the common cancer that affected of Iraqi women. The correlation between ER and PR showed the impotence these markers for progression disease, survival of patients and for determination the required drug. Cyclin $\mathrm{E}$ increased tumor growth and improved invasion of cancer cells by transition cell from gap 1 phase to synthesis phase of cell cycle. There was no correlation between cyclin $\mathrm{E}$ with other receptors.

\section{Authors' declaration:}

- Conflicts of Interest: None.

- We hereby confirm that all the Figures and Tables in the manuscript are mine ours. Besides, the Figures and images, which are not mine ours, have been given the permission for republication attached with the manuscript.

- The author has signed an animal welfare statement.

- Ethical Clearance: The project was approved by the local ethical committee in University of Baghdad.

\section{References:}

1. AICR American Institute of Cancer Research. Diet, Nutrition, Physical activity and breast cancer. World Cancer Research Fund. 2017 .Pp: 4.

2. Martínez-Montiel N, Anaya-Ruiz M, Pérez-Santos M, Martínez-Contreras RD. Alternative Splicing in Breast Cancer and the Potential Development of Therapeutic Tools. Genes. 2017; 8 (217): 1 - 14 . Available from http://www.mdpi.com/journal/genes DOI: $10.3390 /$ genes8100217.

3. ACS American Cancer Society. Cancer Facts and Figures2018. Atlanta. American Cancer Society.Inc.Pp: 1, 12.

4. Saifullah PH, AL-Kazzaz FF, Zayzafoon NN. Study of Malondialdehyde levels in sera, RBCs ant tissues homogenate of Iraqi women with breast tumors. Baghdad Sci J. 2009; 6 ( 3 ) : 553 - 562 .

5. Duffy MJ, Harbeck N, Nap M, Molina R, Nicolini A, Senkus E, et al. Clinical use of biomarkers in breast cancer: Updated guidelines from the European Group on Tumor Markers (EGTM) .Eur J of Cancer. 2017; 75: 284e - 298e. Available from http:// dx.doi.org DOI: 10.1016/j.ejca.2017.01.017.

6. Weigel MT, Dowsett M. Current and emerging biomarkers in breast cancer: prognosis and prediction . EndocrRelat Cancer. 2010; 17 (1): R245 - R262. Available fromhttp://www.endocrinologyjournals.org.DOI: 10.1677/ERC-10-0136.

7. Bjornstrom L, Sjoberg M . Mechanisms of Estrogen Receptor Signaling: Convergence of Genomic and Nongenomic Actions on Target Genes .MolEndocrinol. 2005; 19 (4): 833 - 842. Available from https://academic.oup.com/mend/articleabstract/19/4/833/2741274.DOI: 10.1210/me.20040486.

8. Yue W, Wang J-P, Li Y, Fan P, Liu G, Zhang $\mathrm{N}$, et al. Effects of estrogen on breast cancer development: role of estrogen receptor independent mechanisms. Int J Cancer. 2010; 127 (8): 1748 1757. DOI: $10.1002 / \mathrm{ijc} .25207$.

9. Micheli A, Muti P, Secreto G, Krogh V, Meneghini E, Venturelli E, et al. Endogenous sex hormones and subsequent breast cancer in premenopausal women.Int.J Cancer. 2004; 112 (1):312 - 318 
Available

https://doi.org/10.1002/ijc.20403.DOI: 10.1002/ijc.20403.

10. Majumder A, Singh M, Tyagi SC. Postmenopausal breast cancer: from estrogen to androgen receptor .Oncotarget. 2017; 8 (60): 102739 - 102758.

11. Selli C, Sims AH.Neoadjuvant Therapy for Breast Cancer as a Model for Translational Research . Breast Cancer: Basic and Clin Res. 2019; 13: 1- 7. DOI: 10.1177/1178223419829072.

12. Wang J, Xu B. Targeted therapeutic options and future perspectives for HER2-positive breast cancer .Signal Transduct Target Ther. 2019; 4 ( 34 ) : 1 22.Available from http: // doi. Org DOI: 10.1038/s41392-019-0069-2.

13. Sareyeldin RM, Gupta I, Al-Hashimi I, AlThawadi HA, Al Farsi HF, Vranic S, et al. Gene Expression and miRNAs Profiling: Function and Regulation in Human Epidermal Growth Factor Receptor 2 (HER2)-Positive Breast Cancer. Cancers. 2019; 11 (646): 1 - 20. Available from www.mdpi.com/journal/cancers.DOI: 10.3390/cancers 11050646.

14. Furrer D, Paquet C, Jacob S, Diorio C. The Human Epidermal Growth Factor Receptor 2 ( HER2 ) as a prognostic and predictive biomarker: molecular insights into HER2 activation and diagnostic implications. IntechOpe. 2018; 11 - 31.Available from http : // dx.doi.org DOI: 10.5772/intechopen.78271.

15.Wilson FR, Coombes ME, Wylie Q, Yurchenko M, Brezden-MasleyCh, Hutton B, et al. Herceptin (trastuzumab) in HER2-positive early breast cancer: protocol for a systematic review and cumulative network meta-analysis. Systematic Reviews. 2017; 6 (196): $\quad 1 \quad-\quad$ 8. $\quad$ Available from https://www.crd.york.ac.uk/prospero.DOI: 10.1186/s13643-017-0588-2.

16. Mokuyasu S, Suzuki Y.Clinical Utility of Serum Human Epidermal Growth Factor Receptor Type 2 Testing as a Marker of Therapeutic Response in Tissue HER2-Positive Breast Cancer Patients . Int J Cancer Clin Res. 2017; 4 ( 2 ) : 1 - 6. DOI: 10.23937/2378-3419/1410089.

17. Cianfrocca M, Goldstein LJ. Prognostic and Predictive Factors in Early-Stage Breast Cancer. Oncologist. 2004; 9 : $606-616$.

18.Hatem SF, Alyaqubi KJ, Al-Atrooshi SAB - W, Alsayyid MM, Saad M, Safaa R. The Study of HER-2/neu, ER/PR Expression Using Immunohistochemistry (IHC) in the Iraqi Breast Cancer.Kufa J For Veter Med Sci .2016; 7 ( 1 ): 18 27.

19. Chappuis PO, Donato E, Goffin JR, Wong N, Be'gin LR, Kapusta LR, et al. Cyclin E expression in breast cancer: predicting germline BRCA1 mutations, prognosis and response to treatment. Annals of Oncology.2005; 16: 735 742.Availablefrom

https://academic.oup.com/annonc/articleabstract/16/5/735/150169.DOI:

10.1093/annonc/mdi149.
20. Hwang HC, Clurman BE. Cyclin E in normal and neoplastic cell cycles.Oncogene.2005; 24: 2776 2786. DOI: 10.1038/sj.onc.1208613.

21. Law ME, Corsino PE, Narayan S, Law BK. Cyclin-Dependent Kinase Inhibitors as Anticancer Therapeutics.Mol.Pharmacol.2015; 88: 846 852.Available from http:// dx.doi.org DOI: 10.1124/mol.115.099325.

22. Akli S, Carolyn S, Pelt V, Bui T, Multani AS, Chang S, et al. Overexpression of the Low Molecular Weight Cyclin $\mathrm{E}$ in Transgenic Mice Induces Metastatic Mammary Carcinomas through the Disruption of the ARF-p53 Pathway . Cancer Res . 2007; 67: (15) : 7212 - 7222 . Available from http://cancerres.aacrjournals.org.DOI : 10.1158/00085472.CAN-07-0599.

23.Karakas C, Biernacka A, Bui T, Sahin AA, Yi M, Akli S, et al.CytoplasmicCyclin E and PhosphoCyclin - Dependent Kinase 2 Are Biomarkers of Aggressive Breast Cancer. The Am J of Pathol. 2016; 186 (7): 1900 - 1912. Available from http:// dx.doi.org DOI: 10.1016/j.ajpath.2016.02.024 .

24. Duronio RJ, Xiong Y. Signaling pathways that control cell proliferation. Cold Spring Harbor perspectives in biology. 2013 Mar 1;5(3):a008904.Available from www.cshperspectives.org.DOI: 101101/cshperspect.a008904.

25. Iqbal BM, Buch A. Hormone receptor (ER, PR, HER2/neu) status and proliferation index marker (Ki67 ) in breast cancers: Their onco-pathological correlation, shortcomings and future trends. Med J DYPatil Univ. 2016; 9 (6): 674 - 679.Available from: http://www.mjdrdypu.org/text.asp?2016/9/6/67 4/194180. DOI: 10.4103/0975-2870.194180.

26. Hunt KK, Karakas C, Ha MJ, Biernacka A, Yi M, Sahin AA, et al. Cytoplasmic Cyclin E Predicts Recurrence in Patients with Breast Cancer. Clin Cancer Res. 2016; 0f1 - of12.Available from www.aacrjournals.org.DOI: $\quad 10.1158 / 1078$ 0432.CCR-16-2217.

27. Nuttall FQ.Body Mass Index Obesity, BMI, and Health: A Critical Review. Nutr Today. 2015; 50 (3): $117 \quad-\quad 128 . \quad$ Available from www.nutritiontodayonline.com.DOI: 10.1097/NT.0000000000000092.

28. Mahir W, Rouas L, Ouzir M, Ferhati D, Rhrab B, Alhamany Z, Cherradi N. Correlation of ER, PR and HER2 with clinico-pathological parameters in Infiltrating Ductal Carcinoma of Breast in Morocco .Int J of Innovation and Applied Studies.2016; 14 (2) : 498-506.

29. Arafah M. Correlation of Hormone Receptors with Her-2 Neu Protein Expression and the Histological Grade in Invasive Breast Cancers in a Cohort of Saudi Arabia.Turkish J of Pathol. 2012; 28 (1): 38 43. Available from http://www.endocrinologyjournals.org.DOI: 10.5146/tjpath.2012.01095.

30. Horwitz KB, McGuire WL.Estrogen control of progesterone receptor in human breast cancer correlation with nuclear processing of estrogen 
receptor. The J ofbiol Chem. 1978; 253 (7): 2223 2228.

31. Dubowy RL, Feinberg RF, Keefe DL, Doncel GF, Williams ShC, McSweet JC, et al . Improved endometrial assessment using cyclin E and p27. Fertility and Sterility.2003; 80 (1): 146 - 156. DOI: 10.1016/S0015-0282(03)00573-9.

\section{دراسة بعض الماركرات في النساء العراقيات المريضات بسرطان الثدي}

حيدر لطيف محمد4

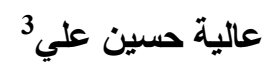

علي حسين محمد الخفاجي

عبير محمد حسين

1 إسم علوم الحباة، كلية العلوم للبنات، جامعة بغداد، بغداد، العراق.

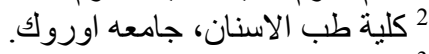

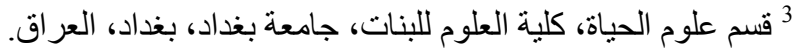

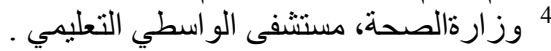

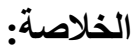

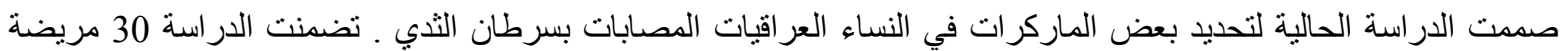

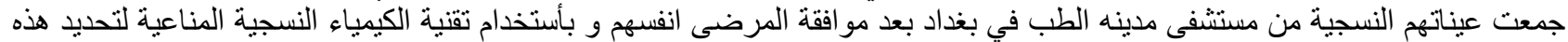

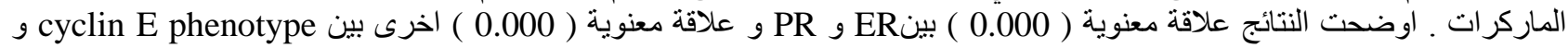
ما يوضح اهمية هذه الماركرات لسرطان الثدي . cyclin E intensity

الكلمات المفتاحية : cyclin E ، Her-2/neu ، PR ، ER و سرطان الثدي . 